\title{
ПАРАДИГМА ГЛОБАЛЬНОГО РОЗВИТКУ: ЗАПИТИ, ВИКЛИКИ, ПРОГНОЗИ
}

\section{Петасюк O. I.}

\section{ВСТУП}

3 початком XXI століття разом із динамічним розвитком глобальної епохи відповідно змінюється і іï парадигма. На сучасному порядку денному цивілізації (глобальне потепління, що поставило людство на межу кліматичної кризи; збій у розподілі виробництва; глибока соціальна нерівність; збройні конфлікти; масова еміграція; міжнародний тероризм; нові віруси, епідемії) містяться питання фундаментальних змін у системах виробництва і споживання, ідеології та технології (загроза неетичного використання технологій, проблема штучного інтелекту, «техноутопізм»). Людство на шляху до оволодіння новими способами використання часу, простору, логіки. Проте перманентний цивілізаційний поступ не убезпечив людину від голодування: за даними Міжнародної організації 3 питань продовольства та сільського господарства при ООН, у 2019 р. у світі потерпало від недоїдання 820 мільйонів людей; більше мільярда людей знаходиться за межею бідності. Однією із гримас цивілізації стало те, що внаслідок поглибленої соціальної диференціації постав нерівномірний доступ до цивілізаційних благ.

Два десятиліття нового століття довели: фундаментальні зміни неминучі. Ми не дискутуємо, чи потрібні вони нам - ми вже у них перебуваємо. Різні майданчики, такі як наукові теорії, 3МІ, Інтернет тощо, задають тон для обговорень, так само глобального мірила, у багатьох аудиторіях світу. Благодатним бекграундом, на який можна спиратися, слугують праці таких дослідників, як Ф. Аінса, М. Бойцов, М. Кундера, В. Ліппман, Е. Тоффлер, Ж. Фреско, Ф. Фукуяма та інші.

Мета статті полягає у тому, щоб репрезентувати найбільш актуальні та оригінальні 3 наукової точки зору погляди та тези щодо позиціювання та якісного наповнення глобальних трансформацій. Задля іï вирішення порушуються такі питання: яка, за великим рахунком, вимальовується у нас на очах картина світу загалом та окремої держави зокрема, чи є вона об'єктивним відображенням 
дійсності; яку роль у цьому процесі відіграють стереотипи, образи, іміджі (проблема створення уявної реальності); чи можлива постановка опозицій глобалізація - «постутопія як раціональний проект ідеального суспільства»; які на сьогодні сучасне людство має виклики у технологічній сфері, зокрема, проблема штучного інтелекту, яка дедалі частіше стає предметом навіть міжнародної політики (до прикладу питання конкурентної боротьби між державами)? Бо, як зауважував Президент Всесвітнього економічного форуму Б. Бренде (Давос, 2020), у сучасному турбулентному глобальному становищі розширюються можливості для конкуренції або співпраці одночасно на декількох напрямах. Головне - прагнути прогресу заради спільних цілей, а не набувати стратегічних переваг. Тим більше, маємо вигоди єдиної глобальної комунікаційної платформи ${ }^{1}$.

\section{1. Картина світу в глобальну епоху: образи, стереотипи, сенси}

Модель світу - це образ світосприйняття, який формується у соціумі. Вона передається і збагачується у процесі історичного розвитку, відтворюється у вигляді культури, показуючи місце людини у світі, іï ставлення до природи, суспільства та самої себе. Картина світу формує спосіб розуміння індивідом сенсу життєдіяльності, дає основний ціннісний орієнтир, уявлення про головні світові події. Універсальні параметри, за допомогою яких люди осмислюють упорядкованість свого світу: простір і час. Відповідно, зміст подій визначається їхнім просторово-часовим положенням.

Сукупність уявлень, ідей людини про дійсність, що іï оточує, концентрується у iï світогляді. У чому полягає складність світосприйняття? 3 одного боку, свідомість людини - це не фотоплівка, яка раз і назавжди зберігає враження (В. Ліппман); дитина, народжена сьогодні, наслідує світ, який дуже відрізняється від того світу, що отримало покоління його батьків (Ж. Фреско). 3 іншого боку, якщо застосувати вираз В. Вжосека щодо історіографії відносно картини світу, то вийде наступне: образ світу, який дає нам його осмислення у різноманітних виявах, - це тільки мисленнєвий його образ і мовний запис. Отже, можливо стверджувати, що людське світосприйняття формує не стільки реальна картина світу, скільки ії відображення. В. Ліппман зосереджується на тезі, що наше знання про світ

1 Бренде Б. Всьому світу пора міняти курс. Що вирішується у Давосі. URL:https://nv.ua/ukr/opinion/davos-2020-roku-pro-shcho-govoryat-svitovi-politikiostanni-novini-50065621.html 
опосередковане 3 тієї причини, що довкілля $є$ надто складним утворенням, що змінюється, щоб можливо було його пізнавати напряму. До того ж існують «сліпі зони»: наші уявлення про зовнішній світ набагато простіші, ніж реальний потік подій, відтак із часом нам відчиняються сліпі зони, які із периферії нашого поля зору переміщуються у центр ${ }^{2}$. Дослідник стояв у витоків імагології, яка вивчає образи різних властивостей, тобто репрезентації та саморепрезентації людини. Термін «образ» 3'явився на сторінках академічних, передусім соціологічних видань у 1920-тих pp. ${ }^{3}$ (В. Ліппман, «Суспільна думка», 1922). Так само 3 ім'ям цього дослідника пов'язаний і термін стереотип - одне із психологічних утворень, хоч і сперте на певний досвід, проте $\epsilon$ відображенням уявлень людей про когось або щось. Стереотип - це прийнятий в історичній спільності зразок сприйняття, інтерпретації інформації під час впізнавання оточуючого середовища, заснований на попередньому соціальному досвіді. За Ж. Фреско, ми не народжуємося із забобонами та нетерпимістю, вони виходять із нашого життєвого досвіду ${ }^{4}$. До розумінь понять «образ», «стереотип» тісно дотичне розуміння «свого» i «чужого», яке виникає на стадії формування етносу і пов'язане із поняттям «самобутність». Самобутність - сукупність рис духовної та матеріальної культури, що історично склалася, характерна для конкретної національно-етнічної спільноти, що відрізняє іiі від відповідних рис іншої спільноти й сприяє формуванню етнічної самосвідомості, що на соціально-психологічному рівні базується на антитезі «ми» і «вони», на уявленні про власні, відмінні від інших, якості. За В. Ліпманом, саме стереотипи маркують об'єктів і суб'єктів на «свої» та «чужі». Уявлення про «своїх» та «чужих» займають центральне місце в ідентифікаціях людських спільнот та в їх моделях світосприйняття. Це важливий аспект у плані становлення національних культур як струмків глобального феномену - світової культури, де процес усвідомлення нацією своєї тотожності із усім людським родом знаходить свій сконцентрований вираз у ціннісних

2 Липпман Уолтер. Общественное мнение. URL: http://baguzin.ru/wp/wpcontent/uploads/2015/02/У олтер-Липпман.-Общественное-мнение.pdf

3 Власть и образ. Очерки потестарной имагологии. Санкт-Петербург : Алетейя, 2010 / За ред. М.А. Бойцова, Ф.Б. Успенского. 384 с. С. 5.

${ }_{4}^{4}$ Фреско Ж. Проектирование будущего. URL: https://www.litmir.me/br/?b= 216216. 
універсаліях. Проте глобальне мислення - це не однотипне світосприйняття, а нова якість єдності у багатоваріантності ${ }^{5}$.

Чи сприймає людство глобалізацію як «раціональний проєкт ідеального суспільства» (Л. Сарджент)? 3 одного боку, існує точка зору, що проєкт «глобалізація в якості постісторичного лібералізму» є утопічним (рефлексії на працю Фукуями «Кінець історії та остання людина», 1992), з іншого - в утопії міститься надія, це знак можливих змін (К. Маннгейм). Ф. Фукуяма застосовує поділ на світи: історія постісторія, між якими у майбутньому виникне конфлікт, бо сили будуть нерівними. Він використовує словосполучення «технологічний раціоналізм сучасності», який держави мають прийняти, якщо хочуть зберегти свою самостійність. На його переконання, людство знаходиться у тисках наукових технологій, проте саме через них воно має можливість себе відтворювати. Оригінальною $є$ його думка: володіння наукою - це та причина, завдяки якій європейці підкорили усі країни, які є зараз третім світом, а дифузія цієї науки дозволила країнам третього світу в XX столітті повернути собі суверенітет ${ }^{6}$. Деякі дослідники інтерпретують теорію «кінця історії» Ф. Фукуями як стереотипне ставлення людини західної культури до представників інших культур.

Як зазначав французсько-уругвайський літературознавець Фернандо Аінса, парадокс сприйняття утопії полягає в наступному: засуджувана за ідеологічні збочини утопія $\epsilon$ необхідною умовою роздумів про майбутні зміни; проєкт майбутнього завжди враховує панівні цінності реального суспільства. «Історія породжує утопії, та й певні утопії творять історію» ${ }^{7}$. Рефлексуючи щодо Нового Світу, дослідник вказував на напругу між реальним та ідеальним, що пояснюється не тільки подвійним характером утопічного дискурсу; рівною мірою вона виходить із природи розколотої американської ідентичності, яка орієнтується одночасно на те, що Америка $\epsilon$ у реальності, і на те, якою вона бажала би бути.

${ }^{5}$ Петасюк О.І. Антропоценричність загальнолюдського та національного як критеріїв культурного прогресу. Міжнар. наук. конф. 22 лютого 2019 р. «Модернізація освітньої системи: світові тенденції та національні особливості», Литва. Каунас : Ун-т В. Великого, 2019. 596 с. С. 345-347.

6 Фукуяма Ф. Конец истории и последний человек. URL: http://lib.ru/POLITOLOG/FUKUYAMA/konec_istorii.txt.

7 Аінса Ф. Чи потрібна утопія? URL: http://www.ji-magazine.lviv.ua/2016/ Ainsa_Chy_potribna_utopiya.htm. 
Спосіб існування свідомості людини - це знання як відображення дійсності на двох полюсах - об'єктивному та суб'єктивному. Головним продуктом цивілізації, передусім глобалізованої, виступають саме знання. У 1930-их роках Ф. Махлуп уводить у дискурс поняття «індустрія знань» (цілісність освіти, науки, ЗМІ, інформаційних технологій та послуг), що вилилося з часом у визначення якісно нової доби людства. Цей концепт у $70-80$ роках $\mathrm{XX}$ століття розвинув Д. Белл, ставши класиком постіндустріального суспільства, де панує верховенство знання. Один із авторів «інформаційної цивілізації» Е. Тоффлер вважав: вона веде до створення надіндустріальної інформаційної цивілізації і пророкував загибель індустріалізму та появу нових джерел енергії, демасифікацію ЗМI, прихід ефективних демократичних урядів та зменшення ролі національних держав («Третя хвиля», 1980). Вже за життя вченого стали справджуватися тоффлерівські прогнози. Невипадково бразильський діяч Октавіо Пас у 1980-х роках запропонував замість терміну «постсучасність» вживати термін «постутопія». Як зазначав Ф. Аінса, утопії містять пророчі візії.

Одним із викликів людству маємо неймовірну швидкість технорозвитку, всепоглинаючу інтернетизацію, штучний інтелект ${ }^{8}$. Вустами Р. Рейгана це виглядає наступним чином: Голіаф тоталітарного контролю буде швидко повалений Давидом мікрочіпу. Про повноцінний штучний інтелект говорити ще зарано, врешті-решт машинний інтелект виступає продовженням інтелекту людини. Проте дослідження штучного інтелекту виливаються у загальний потік технологій сингулярності (видовий стрибок, молекулярна біоелектроніка, теоретична біологія, квантова теорія тощо). Штучний інтелект поглиблює своє проникнення у бізнес-сфери, відоме його застосування у створенні систем ідентифікації загроз супротивника, де у цій галузі він виступає трендом. Нині $є$ багато підходів до розуміння штучного інтелекту. Одні позиціонують його як комп'ютерні системи, які мають ознаки мислення (системи, які, оперуючи знаннями, самі навчаються). Інші вбачають у цьому загрозу для людства: штучний інтелект може вийти 3-під контролю. Підприємець та винахідник Ілон Рів Маск 2017 р. наголосив: «Найменш страшне майбутнє, про яке я можу думати, це те, де ми матимемо демократичний штучний інтелект, тому що якщо одна компанія чи невелика група людей встигне

8 Дубовий М. Світ більше не буде колишнім. Що чекає планету в майбутньому? URL: https://www.obozrevatel.com/ukr/society/yakoyu-budeplaneta-v-majbutnomu-zyavivsya-analiz-dopovidi-rimskogo-klubu.htm. 
розвинути богоподібний цифровий супер-інтелект, вони можуть захопити світ» ${ }^{9}$. На арену вийшов ще один «утопізм» 3 приставкою техно-. Опоненти цього світобачення наголошують: якщо технології вирішать усі проблеми, то тоді не буде потреби у пошуку комплексних проблем ${ }^{10}$. Спочивання на лаврах - це небезпечне для людського інтелекту явище. 3 цього виходить і такого роду проблема: ряд професій стануть незатребуваними. 3 іншого боку, станеться це не в одну мить. На їх місце прийдуть нові спеціальності, бо нові технології породжують новий попит. До цього ще додається небезпека неетичного використання технологій. До прикладу, моральною і науковою проблемою кінця XX - початку XXI століття виступає клонування людини. Не меншої шкоди завдають цивілізації інші глобальні проблеми: продукування фейкової інформації, інтернетпіратство тощо. Звільнення людства від проблем технологічними шляхами можливе тільки тоді, коли відбуватиметься в гуманних цілях.

Апологети «техноутопізму» говорять про технологічну сингулярність - гіпотетичне зростання науково-технічного прогресу, що прослідує за винайденням штучного інтелекту, здатного до інтеграції людини з електронно-обчислювальними машинами. Інженер i футуролог Ж. Фреско вважав, що наука не створила жодної із проблем людства: «Наші проблеми виросли із зловживання і експлуатації інших людей, довкілля і технологій» («Проектування майбутнього»). Ось такі техноштрихи до сучасної картини світу. Напевне, як на сьогодні, у ній будуть ще невиявлені «сліпі зони». Проте вже на цей час маємо реальні перспективи. Надії покладаються, по-перше, на використання штучного інтелекту для управління мережами стільникового зв'язку; по-друге, залучення штучного інтелекту для аналізу наукових публікацій з метою синтезу знань; потретє, інтеграція спеціалізованих систем штучного інтелекту до можливостей людини та багато іншого. Кінцевою метою досліджень у цій царині є розкриття сенсів мислення та створення моделі мозку, бо це ще досі залишається серед таємниць буття.

На нашу думку, іншим помітним штрихом сучасної картини світу $\epsilon$ сприйняття глобалізації як поглибленої інтеграції передусім

9 Авторитарні режими, штучний інтелект та «безсмертний диктатор, якого ми ніколи не позбудимося». URL: https:/www.radiosvoboda.org/a/29170900.html.

10 Дубовий М. Світ більше не буде колишнім. Що чекає планету в майбутньому? URL: https://www.obozrevatel.com/ukr/society/yakoyu-budeplaneta-v-majbutnomu-zyavivsya-analiz-dopovidi-rimskogo-klubu.htm. 
політичного та економічного гатунку. Саме внаслідок глобалізації виникли такі острови «наднаціонального врядування», як, наприклад, COT та ЄC (із спільними механізмами регулювання спільноти) ${ }^{11}$. Інтеграційні об'єднання виступають елементами світового господарства. На погляд засновника соціоекономіки американця А. Етціоні, якщо ми позиціонуємо співтовариство як систему, то інтеграція буде виступати здатністю цієї системи підтримувати саму себе. Учений наводить приклад із Інтернетом: Інтернет не контролюється національним або інтернаціональним урядом, але при цьому він саморегулюється на глобальному рівні ${ }^{12}$. Трактована економічно глобалізація - це потоки капіталів, товарів, послуг, людських ресурсів без мит, тарифів та квот; соціально-політичне трактування полягає у наголосі на становленні нових форм урядування і влади, формуванні нових арен політичної діяльності, новому розумінні ідентичності спільнот. Один із сенсів інтеграції якраз і полягає у викристалізовуванні нової надсистемної ідентифікації. Американо-німецький соціолог та політолог чеського походження К. Дойч, як автор комунікативної теорії, пропонував називати подібне об'єднання «плюралістичною спільнотою безпеки», в якій існує розуміння того, що усі їі частини відображення єдиної цілісності ${ }^{13}$. Глобальними тенденціями можна пояснити і зростання великої кількості міжнародних організацій (понад чотири тисячі на цей момент), яких маркують як за функціональними особливостями, так i за територіальним мірилом. Засновник менеджменту як дисципліни Пітер Фердинанд Друкер також мав пророчу візію, сказавши: «Функціонування, якщо не виживання сучасного суспільства, залежить від ефективності великих організацій, від їхньої продуктивності та результатів, від їхніх цінностей, стандартів та вимог, які вони до себе

${ }^{11}$ Гарел Е. Глобалізація. Короткий оксфордський політичний словник / пер. 3 англ. / за ред. I. Макліна, А. Макмілана. Київ : Вид-во Соломії Павличко «Основи», 2006. С. 129.

12 Новая глобальная архитектура: механизмы перехода. Стенограмма лекции А. Етциони. 3 апреля 2009. URL: https://polit.ru/article/2009/04/17/ principes/.

13 Рябінін Є. Процеси інтеграції у XX столітті: основні концепції їх вивчення. Політичний менеджмент. 2006. № 5. С. 128-129. URL: http://dspace.nbuv.gov.ua/bitstream/handle/123456789/9649/12-

Riabinin.pdf?sequence=1. 
висувають» ${ }^{14}$. Рух органічного поєднання «національна-глобальна ідентичність» та наявність консенсусу відносно фундаментальних цінностей виступають умовою успішності не тільки інтегрування, а й цивілізаційного поступу, коли усе відбуватиметься заради спільних цілей людського роду.

\section{2. Образ держави як маркер та засіб ідентифікації}

Сучасні перетворення на глобальному рівні засвідчують, що майбутнє націй і континентів залежить від їх уміння володіти та розпоряджатися інформацією, передусім інформацією про самих себе. Усі, як окремі живі об’єкти, так і мікро- та макроспільноти, існують в інформаційному полі. Загалом здавна призначення людини полягало в тому, щоб збирати та накопичувати розсіяну в довкіллі інформацію суголосно високим духовним сенсам.

Інформація є однією із форм відображення, уявлення, роз'яснення реальності. Компоненти довкілля також виступають одними із каталізаторів процесу формування моделі світосприйняття на певному етапі розвитку людства. Образ світу, який дає нам його осмислення у різнобічних виявах - це мисленнєвий його образ і мовний запис. Ми навіть часто-густо чуємо вислів, що поки річ не названа, вона не існує.

У нову епоху на перший план у дослідників виходить образносимволічний бік держави, влади (до прикладу, потестарна імагологія). Відображення як давніх, так і нинішніх, універсальних ефективних практик візуального виразу відносин усередині держави та ії владних структур репрезентують візуальні образи ${ }^{15}$. Актуалізація цієї тематики у нинішньому суспільстві, внаслідок сучасних суттєвих змін та очікувань від майбутнього, пожвавила увагу до загалом «образів нації», розуміння того, що було головним у минулому, на що орієнтуватися у прийдешньому.

Наведу візуальний ряд, за яким можливе маркування української ідентичності: за елементами природного ландшафту (Дніпро, Українські Карпати, калина, тополя, соняшник тощо); штучний ландшафт (Кисво-Печерська Лавра, гетьманська резиденція Батурин, Камянець-Подільський замок, Хотинська фортеця тощо); тварини, птахи, їх варіації на зображеннях та у виразах (лев на гербі Галицько-

14 Друкер П. Ефективний керівник / пер. 3 англ. Р. Машкової. Київ : Вид. група КМ-БУКС, 2018. С. 230.

15 Власть и образ. Очерки потестарной имагологии. Санкт-Петербург : Алетейя, 2010 / За ред. М.А. Бойцова, Ф.Б. Успенского. 384 с. С. 11, 18. 
Волинського князівства та емблемах Січових стрільців, пташина (ластівчина) подоба герба-тризуба, «солов”іна мова» та інші). Маркування може відбуватися за символами у кольорах: малиновий прапор Війська Запорізького; блакитно-жовтий прапор; червоно-чорна емблема; золотий тризуб на синьому щиті; блакитні шаровари; за традиційним одягом: вишиванка, очіпок, віночок, жупан, свита; символи, атрибути влади та військове мистецтво: штандарт, булава, пірнач, гербова печатка, клейнод, корогва (хоругва), човен-чайка, «рухома фортеця», «маяки», «козацький підводний човен» тощо.

Крім візуальних, образ вбирає у себе і тактильні та нюхові (наприклад, загального плану, як-от «запах влади», «важка атмосфера репресій», «палаючі шини»; кулінарні образи як-от «борщ», «галушки», «вареники»), акустичні символи і знаки. Щодо останніх, то маємо у нашій історії такі «репрезентативні звуки», як козацькі сурми, які грали до бою; колядки, щедрівки; гуцульська трембіта; кобза (відповідно стародавній, символічний образ козака Мамая, який грає на кобзі), кобзарі (також символічна назва Шевченкової збірки). Міцно увійшли до українського народного інструментарію та слововжитку ліра, цимбали, бандура - символи-образи європейського походження, які органічно прижилися на українському грунтові. Окремої згадки вартий «дзвін», який був багатофункціональним (як і трембіта): скликання народу на віче; православні канонічні види церковного дзвону, зокрема «благовіст», тощо. Символьні знаки, поняття можливо також розрізняти за політичними, соціальними, економічними та мистецькими ознаками.

Загальний образно-символьний ряд щодо України виглядатиме наступним чином: прийняття християнства; гривна, Запорозька Січ; гетьман; «оселедець»; Києво-Могилянська академія; універсал; Мазепинці; гайдамаки; громада; кооперація; чумацька артіль; художники-авангардисти; Голодомор-геноцид; криївка; шістдесятники; лірична пісня. Під час наведення асоціативного ряду я послугувалася передусім інформаційним полем, яке оточує мене у силу професії. Україна XXI століття асоціюється із образами Майдан, Помаранчева революція, Революція гідності - символами боротьби за право власного вибору, символами того, що за цей вибір українці готові покласти власне життя. Із горнила Євромайдану виросли символічні зображення, поняття, гасла (певні відродилися із небуття): чоловік у захисній касці і саморобним щитом; Небесна сотня; «Слава Україні!»; сотня, коліївщина, побратими, національна гвардія, кіборги, пісня «Пливе кача». Більшість символів Євромайдану водночас 
і політичні, i мистецькі: в історично-культурологічному вимірі поєдналися політика, символ, культура. За М. Бойцовим, образи, які народжуються в індивідуальній свідомості, суцільно опиняються конвенціональними, які задані індивіду ззовні загальними установкам культури ${ }^{16}$.

Людське світосприйняття формує не стільки реальна картина світу, а іiї відображення, або те, як іiі репрезентують реципієнту. Зокрема, від науковців, public relations чи ЗМІ у цьому плані багато чого залежить, бо вони не тільки інтерпретують факти, а й наділяють сенсом досліджувані явища, розставляючи власні акценти. У чому небезпека? Безвідповідальні інтерпретатори дійсності маніпулюють інформацією, створюючи фейки, пропагандистські кліше, історичні міфи та міфологеми тощо. Використовуються при цьому усі майданчики: наукові теорії, TV-канали та радіо, Інтернет-канали, «ботоферми» та інше. Свідомо спотворюється реальна картина світу загалом та образ окремої держави зокрема. Ситуація ускладнена тим, що це відбувається в умовах сучасного глобального турбулентного становища.

В епоху глобалізації та інформаційних воєн, по-перше, держави, які дбають про власне майбутне, не можуть дозволити собі розкіш недооцінювання такої інформаційної зброї, як концептуальнометодологічна, хронологічна, фактологічна. Вона виступає форпостом держави як у плані внутрішньої консолідації, так і на зовнішньому інформаційному фронті. По-друге, не варто очікувати, що образ країни сформується сам по собі, спонтанно, без докладання до цього зусиль, передусім державних. Голос окремих інформаційних волонтерів (блогери, заходи діаспори, інтернет-проєкти, наприклад, «Стопфейк», група «Інформаційний спротив») на цій ділянці фронту, без державної політики та підтримки, потоне у масованих, перманентних інформаційних атаках супротивника, на які він кидає потужні фінанси. До прикладу: Російська Федерація щороку витрачає на проведення інформаційної кампанії («м'який вплив» на закордонну аудиторію) не менше 3,5 млрд дол. $\mathrm{CWA}^{17}$. Зокрема, тільки у Німеччині

16 Власть и образ. Очерки потестарной имагологии. Санкт-Петербург : Алетейя, 2010 / За ред. М.А. Бойцова, Ф.Б. Успенского. 384 с. С. 14.

${ }^{17}$ Скільки Росія витрачає на інформаційну війну в Україні. ІНФОГРАФІКА. URL: https://informnapalm.org/ua/skilky-rosiya-vytrachaye-na-informatsijnu-vijnuv-ukrayini-infografika/. 
російськомовних 3МІ більш ніж чотириста назв (Б. Неміровський) ${ }^{18}$. Гібридна війна, розв'язана Росією в Україні, тільки частково ведеться традиційною зброєю. До інформаційного компоненту російської агресії входять: комплекси радіорозвідки, субсидіювання проросійських ідеологічних рухів та регіональних ЗМІ на окупованих територіях, підтримка Інтернет онлайн каналів, ретрансляція пакету федеральних ТВ каналів, друкована преса тощо. Так само досить потужною $є$ російська система медійного впливу в європейському інформаційному просторі: тільки на потреби Всеросійської державної теле- та радіотрансляційної компанії у 2015 р. було заплановано приблизно 55 млрд руб., 3 яких 12,2 млрд спрямовувалося на «формування об'єктивного образу Р. за кордоном»; за різними даними, бюджет МІА «Росія сьогодні» на 2015 р. складав 650 млн дол. США ${ }^{19}$. На 2019 р. видатки на просування іміджу України становили 147 млн грн (держбюджет) ${ }^{20}$.

На державному рівні важливість створення іміджу України було вперше зафіксовано в «Основних напрямах зовнішньої політики України» (1993), де у першому розділі серед завдань зовнішньої політики фігурувало: поширення у світі образу України як надійного, передбачуваного партнера. Стаття 18 Конституції України (1996) декларує: зовнішньополітична діяльність держави спрямована на забезпечення іiї національних інтересів шляхом підтримання мирного співробітництва 3 країнами за загальновизнаними нормами міжнародного права. Важливими віхами у цьому процесі є Державна цільова програма формування позитивного міжнародного іміджу України на період до 2011 р. (2009); створення Міністерства інформаційної політики (2014); Концепція популяризації України у світі (2016); Доктрина інформаційної безпеки України (2017); Закон «Про основні засади забезпечення кібербезпеки України» (2018). Нагальними завданнями щодо просування іміджу України $є$ не тільки належне державне фінансування іміджевої політики, а i єдина державна координація усіх сил на даній ділянці та формування

18 Очима Свропи: який образ України формують закордонні 3МI «БлогПост» URL: https://www.5.ua/polityka/ochyma-yevropy-iakyi-obraz-ukrainyformuiut-zakordonni-zmi-blohpost-188359.html

${ }^{19}$ Скільки Росія витрачає на інформаційну війну в Україні. ІНФОГРАФІКА. URL: https://informnapalm.org/ua/skilky-rosiya-vytrachaye-na-informatsijnu-vijnuv-ukrayini-infografika/.

20 Максак Г. Просування іміджу України закордоном. URL: http://fpp.com.ua/topic/prosuvannya-imidzhu-ukrayiny-za-kordonom/. 
стратегічних наративів, які мають виступати фундаментом праці із просування іміджу та національних інтересів ${ }^{21}$.

Свого часу німецький філософ М. Гайдеггер зазначав, що він $є$ тим, що каже, тим самим акцентуючи увагу на непересічному значенні саме мовного відтворення дійсності. У цьому сенсі важливими і багатими $\epsilon$ мовні образи держави. До прикладу, наступний образний ряд відносно історії та культури України: пам'ятки української мови, літератури та писаного права, як-от: «Повість минулих літ», «Руська правда», український епос (думи), «Енеїда» та інші; метафоричні образи («колиска української державності», «козацька християнська республіка», «тримати булаву», «корабель української державності»; образні назви періодів та подій - «Руїна», «козацьке (Мазепинське) бароко», «Конституція Орлика», «національно-визвольні змагання», «розстріляне відродження», «незгодні: українська інтелігенція у русі опору», «живий ланцюг на День Соборності» тощо).

Особливий сенс тут має і дискурс, «своєрідна мова в мові». Дискурс існує тільки у текстах. Це один із можливих альтернативних світів. Феномен дискурсу чітко проявлявся у радянській практиці, коли гнучкість слів навмисне використовувалась лідером для маніпуляції суспільством. Радянська мова (дискурс) виступала системою, в якій за словами переставала існувати реальність, а на арену виходила псевдореальність, де знищувались будь-які засоби логічного мислення (пригадаймо утопію Джорджа Орвелла «1984»). Наприклад, конструкція, де поняття вживаються як синоніми, хоч такими не $\epsilon-$ «партія $=$ народ $=$ комуністи $=$ радянські люди $=$ усе прогресивне людство» ${ }^{22}$. Сьогодні завдяки можливостям сучасної інформаційної російської пропаганди створилася особлива ірреальна дійсність. Такій інформації притаманна кітчева манера подачі (морально-етична маргинальність). Клішованими прикладами слугують: російськомовний мем «Ихтамнет», «розіп'ятий хлопчик у Слов'янську», «Росія - єдина країна у світі, яка здатна перетворити США на ядерний попіл» тощо. Водночас моральні регулятиви буття відкидаються, а саме вони $є$ духовно-практичними скрижалями людського світовідчуття та співіснування. Як відзначав американський історик

21 Максак Г. Просування іміджу України закордоном. URL: http://fpp.com.ua/topic/prosuvannya-imidzhu-ukrayiny-za-kordonom/.

22 Загороднюк В. Мова і дискурс: ущербність “новоязу” Філософія: Cвim людини. Курс лекцій: Навч. посібник / В.Г. Табачковський, М.О. Булатов, Н.В. Хамітов та ін. Київ : Либідь, 2003. С. 389. 
T. Снайдер 2014 p., російська пропаганда стала настільки самосуперечливою, що затьмарила самого Дж. Орвелла ${ }^{23}$.

Одним із чинників, що заважає ефективному формуванню експортного варіанту образу України, є відсутність належного образу усередині країни. Важкі реалії російсько-української війни посприяли укоріненню ідентифікацій. Наприклад, згідно 3 дослідженнями Демократичних ініціатив ім. I. Кучеріва 2020 р. 81\% громадян погоджуються, що українська мова $\epsilon$ важливим атрибутом незалежності України; повсякденне спілкування державною мовою серед ознак патріотизму назвали $35 \%{ }^{24}$.

У січні 2020 р. держсекретар США М. Помпео заявив, що Україна $\epsilon$ не просто географічним серцем у Свропі, а $є$ оплотом і фортецею між Східною Свропою і авторитаризмом. Під час свого візиту до України (лютий 2020 р.) Президент Туреччини Р.Т. Ердоган, вітаючись із Почесною вартою Президента України біля Маріїнського палацу, виголосив: «Слава Україні!» і отримав традиційну відповідь: «Героям слава!». Маємо зусилля поодиноких зарубіжних ентузіастів, які привертають увагу до України через призму, зокрема, сприйняття окупації районів Донецької та Луганської областей. До прикладу, мурал австралійського художника Гвідо Ван Хелтена в Авдіївці, який він назвав «Обличчя війни» (зображення вчительки української мови М. Марченко). Або японця Хірано Такаші, журналіста, викладача японської мови у Львові, який самотужки вивчив українську мову і редагує японську версію сайту «Укрінформ».

Природно, що формування позитивного іміджу країни у світі залежить від ставлення іiі громадян до власної країни, іiї історії та культури. Об'єктивовані образи дійсності зазвичай $є$ як виразом певного погляду на неї (враження від неї), так і способом впливу на ту ж дійсність одночасно ${ }^{25}$. Відтак маємо гнучкість образу та іміджу. Іміджеві характеристики є рукотворними та мобільними, ними можна керувати. Імідж - це те, до чого ми прагнемо, використовуючи методи

23 Снайдер Т. Украинская история, российская политика, европейское будущее. Київ : ДУХ І ЛІТЕРА. 2014. С. 224.

24 Лачихіна А. Російська мова та український патріотизм. URL: https://nv.ua/ukr/opinion/ukrajinska-chi-rosiyska-mova-shcho-potribno-ukrajiniostanni-novini-50068225.html.

25 Власть и образ. Очерки потестарной имагологии. Санкт-Петербург : Алетейя, 2010 / За ред. М.А. Бойцова, Ф.Б. Успенского. 384 с. С. 15. 
індивідуалізації, акцентуалізації та просунення ${ }^{26}$. У контексті розглядуваної проблематики імідж позицінується і як інтерпретація або репрезентація образу. Як влучно зазначав англійський дипломат та прозаїк С. Моем, невідомі люди часто-густо бувають самі собою. Тобто відносно окремої країни у цьому значенні можна стверджувати, що якщо вона не опікується власним іміджем, матиме просто образ у світі. I, як водиться, якщо країна методично не випродуковує інформацію про себе, то прогалини будуть заповнюватися ззовні (послуговування чужим інформаційним полем, 3 якого будуть брати недоброякісну та упереджену інформацію). Нині не потрібно доводити, що уява про державу впливає і на саму державу.

Усі гібридні виклики, які маємо, мусимо сприймати не лише як загрози, а і як можливості для поступу у популяризації нашої держави. Нам $є$ чим пишатися на кожному етапі історії. Україна стане значимою у світі через інформацію про свої давні державницькі традиції, військове мистецтво, багату культурну, інтелектуальну спадщину та набутки сучасників. Як на мене, українці не повинні займатися психологічним мазохізмом (самобичування; комплекси історичної скромності; отримання задоволення від борсання у бруді, особливо під час політичних перегонів). Кожна держава вартує рівно стільки, наскільки сам себе позиціонує.

\section{ВИСНОВКИ}

Сучасна адженда цивілізації засвідчує, що фундаментальні зміни не просто неминучі, ми вже живемо у них. Оригінальним майданчиком обговорень глобального мірила у футурологічному форматі слугують «постутопії», в яких містяться не тільки відповіді на нагальні запити та виклики, а й пророчі візії. Помітними штрихами сучасної картини світу $\epsilon$ висока швидкість технологічного розвитку, всепоглинаюча інтернетизація, штучний інтелект, поглиблена інтеграція. Глобальне мислення не $\epsilon$ однотипним світосприйняттям, а $є$ виявом нової якості єдності у багатоваріантності. Глобалізація не знімає із порядку денного вибудовування державами своїх образів та іміджів.

Осмислення феномену глобального розвитку, його парадигми через призму висвітлення картини світу загалом та образу окремої держави зокрема дає можливість констатувати, що об'єктивовані образи картини світу є одночасно як враженням від неї, так і способом впливу

26 Почепцов Г.Г. Имидж-мейкер. Паблик рилейшнз для политиков и бизнесменов. Киев : Рекл. агентство Губерникова, 1995. С. 177. 
на неї. Образний світ дійсності розвивається паралельно із реальним. Відтак якісне наповнення глобальних трансформацій залежить однаковою мірою від об'єктивних і суб'єктивних факторів. Осмислення образу світу у різних виявах - це мисленнєвий його образ та мовний запис.

Образ вбирає символи і ознаки різних гатунків, які маркують за візуальними, акустичними, нюховими, мовними ознаками; економічними, політичними, соціальними та мистецькими ознаками. Образний світ $є$ відображенням світу реального, тоді як іміджевий світ - бажаного. Іміджеві характеристики є керованими. Держава має бути зацікавлена у створенні як матеріальних, так i символьних ресурсів просування свого образу. Ти значимий рівно настільки у світі, наскільки себе у ньому репрезентуєш.

Гібридні виклики сучасного турбулентного становища маємо сприймати не тільки як загрози, а також як можливості для поступу у популяризації держави, яка має надзвичайно яскраві знаковосимвольні ряди свого образу, сперті на багатий історичний досвід. Символьно-образний ряд людського світосприйняття заданий індивіду ззовні загальними установками культури. Важливий акцент полягає і в тому, що світосприйняття людини формує відображення того, що їй репрезентують як реципієнту. Позитивний імідж держави залежить і від ставлення до неї іiї громадян. Отже, усі ці процеси взаємопов’язані і взаємозумовлені.

\section{АНОТАЦІЯ}

Пропонована увазі читачів розвідка є осмисленням місця картини світу у світогляді людини глобальної епохи. Порушуються проблеми образу держави як маркера та засобу ідентифікації у сучасному світі. Репрезентовані погляди та тези щодо позиціювання та якісного наповнення глобальних трансформацій з «постутопічної» точки зору. 3'ясовуються питання: які застереження існують щодо прийдешніх змін?; чи є глобалізація «постутопією», яка стала зреалізовуватися?; чи може бути об'єктивним відображення дійсності у картині світу; яке місце у ній займають образи, стереотипи, іміджі. Наводяться штрихи сучасної картини світу (динаміка розвитку технологій, інтернетизації, штучного інтелекту, політично-економічної інтеграції); знаковосимвольні ряди сприйняття образу України (візуальні, акустичні, мовні та інші). Наголошується, що майбутне держав залежить від їх уміння володіти та розпоряджатися інформацією про себе. Уявлення про державу впливають і на формування самої держави. 


\section{ЛІТЕРАТУРА}

1. Бренде Б. Всьому світу пора міняти курс. Що вирішується у Давосі. URL: https://nv.ua/ukr/opinion/davos-2020-roku-pro-shchogovoryat-svitovi-politiki-ostanni-novini-50065621.html.

2. Липпман Уолтер. Общественное мнение. URL: http://baguzin.ru/wp/wp-content/uploads/2015/02/Уолтер-Липпман.-

Общественное-мнение.pdf

3. Власть и образ. Очерки потестарной имагологии. СанктПетербург: Алетейя, 2010 / За ред. М. А. Бойцова, Ф. Б. Успенского. $384 \mathrm{c}$.

4. Фреско Ж. Проектирование будущего URL: https://www.litmir.me/br/?b=216216.

5. Петасюк О.I. Антропоценричність загальнолюдського та національного як критеріїв культурного прогресу. Міжнар. наук. конф. 22 лютого 2019 р. «Модернізація освітньої системи: світові тендениії та нащіональні особливості», Литва. Каунас : Ун-т В. Великого, 2019. 596 с. С. $345-347$.

6. Фукуяма Ф. Конец истории и последний человек. URL: http://lib.ru/POLITOLOG/FUKUYAMA/konec_istorii.txt.

7. Аінса Ф. Чи потрібна утопія? URL: http://www.jimagazine.lviv.ua/2016/Ainsa_Chy_potribna_utopiya.htm.

8. Дубовий М. Світ білыше не буде колишнім. Що чекає планету в майбутньому? URL: https://www.obozrevatel.com/ukr/society/yakoyubude-planeta-v-majbutnomu-zyavivsya-analiz-dopovidi-rimskogoklubu.htm.

9. Авторитарні режими, штучний інтелект та «безсмертний диктатор, якого ми ніколи не позбудемося». URL: https://www.radiosvoboda.org/a/29170900.html.

10. Гарел Е. Глобалізація. Короткий оксфордський політичний словник / пер. з англ. / за ред. І. Макліна, А. Макмілана. Київ : Вид-во Соломії Павличко «Основи», 2006. С. 127-130.

11. Новая глобальная архитектура: механизмы перехода. Стенограмма лекции А. Етциони. 3 апреля 2009. URL: https://polit.ru/article/2009/04/17/principes/.

12. Рябінін $\mathrm{C}$. Процеси інтеграції у XX столітті: основні концепції їх вивчення. Політичний менеджмент. 2006. № 5. С. 122-130. URL: http://dspace.nbuv.gov.ua/bitstream/handle/123456789/9649/12Riabinin.pdf?sequence $=1$.

13. Друкер П. Ефективний керівник / пер. 3 англ. Р. Машкової. Київ : Вид. група КМ-БУКС, 2018. 248 с. 
14. Скільки Росія витрачає на інформаційну війну в Україні. IНФОГРАФІКА. URL: https://informnapalm.org/ua/skilky-rosiyavytrachaye-na-informatsijnu-vijnu-v-ukrayini-infografika/.

15. Очима Європи: який образ України формують закордонні 3МI «БлогПост» URL: https://www.5.ua/polityka/ochyma-yevropy-iakyi-obrazukrainy-formuiut-zakordonni-zmi-blohpost-188359.html.

16. Максак Г. Просування іміджу України закордоном. URL: http://fpp.com.ua/topic/prosuvannya-imidzhu-ukrayiny-za-kordonom/.

17.Загороднюк В. Мова i дискурс: ущербність "новоязу" Філософія: Світ людини. Курс лекиій: Навч. посібник / В.Г. Табачковський, М.О. Булатов, Н.В. Хамітов та ін. Київ : Либідь, 2003. $432 \mathrm{c}$.

18. Снайдер Т. Украинская история, российская политика, европейское будущее. Київ : ДУХ І ЛІТЕРА. 2014. 248 с.

19. Лачихіна А. Російська мова та український патріотизм. URL: https://nv.ua/ukr/opinion/ukrajinska-chi-rosiyska-mova-shcho-potribnoukrajini-ostanni-novini-50068225.html.

20. Почепцов Г.Г. Имидж-мейкер. Паблик рилейшнз для политиков и бизнесменов. Київ : Рекл. агентство Губерникова, 1995. 235 с.

\section{Information about author: Petasyuk O. I.,}

Candidate of Historical Sciences, Associate Professor, Associate Professor of the Department of Contemporary History of Ukraine Taras Shevchenko National University of Kyiv 60, Volodymyrska Str., Kyiv, 01033, Ukraine 